\title{
Glyceraldehyde-3-phosphate dehydrogenase is negatively regulated by ADP-ribosylation in the fungus Phycomyces blakesleeanus
}

\author{
Martha Deveze-Alvarez, Jesús García-Soto \\ and Guadalupe Martínez-Cadena
}

Author for correspondence: Guadalupe Martínez-Cadena. Tel: +52 47324302 8164. Fax: +52 47324302

8153.e-mail:margua@quijote.ugto.mx

Instituto de Investigación en Biología Experimental, Facultad de Química, Universidad de Guanajuato, Apdo. postal 187, Guanajuato, Gto, 36000 Mexico

\begin{abstract}
Dormant spores of Phycomyces blakesleeanus contain a $37 \mathrm{kDa}$ protein that is endogenously mono-ADP-ribosylated. This protein was purified and identified as glyceraldehyde-3-phosphate dehydrogenase (GAPDH) by $\mathrm{N}$ terminal sequencing and homology analysis. GAPDH enzymic activity changed dramatically upon spore germination, being maximal at stages where ADPribosylation was nearly undetectable. The presence of glyceraldehyde 3phosphate in this reaction affected the [ ${ }^{32}$ P]ADP-ribosylation of the GAPDH. ADP-ribosylation of the GAPDH occurred by transfer of the ADP-ribose moiety from NAD to an arginine residue. A model for the regulation of GAPDH activity and its role in spore germination in $P$. blakesleeanus is proposed.
\end{abstract}

Keywords: regulation, spores, germination, zygomycete, GAPDH

\section{INTRODUCTION}

In many fungi the spores do not germinate when provided with conditions suitable for growth of the organism. Instead, they require activation via physical or chemical treatment. The spores of the zygomycete fungus Phycomyces blakesleeanus must be activated by heat shock or treatment with certain monocarboxylic acids in order to germinate and grow in a suitable culture medium (Van Laere, 1986).

Although dormant spores exhibit a very low metabolism, the components of most pathways are present and ready to operate (Van Laere et al., 1987). Upon germination, rapid metabolic changes occur which include an increase in the concentration of fructose 2,6bisphosphate, and in trehalase activity. The latter is regulated by phosphorylation, most probably through a cAMP-dependent protein kinase (Van Laere \& Hendrix, 1983; Van Mulders \& Van Laere, 1984; Van Laere et al., 1987). In addition to trehalase, other enzymes associated with germination have been isolated and characterized in some detail. One of these proteins is glycerol-3phosphatase. When measured under physiological conditions, glycerol-3-phosphatase is activated both in vivo and in vitro by a cAMP-dependent process (Van Schaftingen \& Van Laere, 1985). More recently, we have

Abbreviations: GAPDH, glyceraldehyde-3-phosphate dehydrogenase; GA3P, glyceraldehyde 3-phosphate. identified mono(ADP-ribosyl)transferase activity in spores of $P$. blakesleeanus, but its role in the germination process of this fungus remains unclear (Deveze-Alvarez et al., 1996).

Mono-ADP-ribosylation, like phosphorylation, is a post-translational modification and is effected by the enzymic transfer of the ADP-ribose moiety from $\mathrm{NAD}^{+}$ with release of nicotinamide. ADP-ribosylation often results in activation of the target protein. Some of the transferases can also use an amino acid or water instead of the amino acid in the target protein as an acceptor. Some of the transferases also catalyse the covalent attachment of ADP-ribose to themselves. Mono(ADPribosyl)transferase enzymes have been identified in different eukaryotic cells and tissues. Most of the characterized enzymes catalyse the transfer of ADPribose from NAD to arginine (Williamson \& Moss, 1990). A cysteine-specific ADP-ribosyltransferase has been purified from human erythrocytes (Jacobson et al., 1990), but its endogenous substrates are poorly characterized.

ADP-ribosylation is a reversible modification of proteins. That is, both ADP-ribosyltransferases and ADPribosylhydrolases have been identified in animal tissues (Williamson \& Moss, 1990; Moss et al., 1985). The role of mono-ADP-ribosylation in eukaryotic cells is less well characterized than in prokaryotes, although it has been suggested by different authors that this modification is involved in a number of biological processes. 
Mono-ADP-ribosylation in eukaryotes has been implicated in modulation of cell-cell interactions, signal transduction, the architecture of the cellular cytoskeleton, and vesicular transport (Koch-Nolte \& Haag, 1997).

We are interested in revealing the biochemical and molecular mechanisms involved in spore germination. In the present study, we have identified the enzyme glyceraldehyde-3-phosphate dehydrogenase (GAPDH) as one of the substrates of the arginine-specific ADPribosyltransferase present in dormant spores of $P$. blakesleeanus. We have also shown that ADP-ribosylation inhibits the enzymic activity of GAPDH and that this inhibition is overruled by glyceraldehyde 3phosphate (GA3P).

\section{METHODS}

Preparation of cytosolic fractions (S31K). The wild-type strain of P. blakesleeanus NRRL 1555(-) (Northern Regional Research Laboratory, Peoria, IL, USA) was used throughout this study; it was maintained on slants of YPG medium (Bartnicki-García \& Nickerson, 1962). Spores were harvested as described by Martínez-Cadena \& Ruiz-Herrera (1987). To promote germination and growth, the spores were heat shocked $\left(48^{\circ} \mathrm{C}, 15 \mathrm{~min}\right)$ before inoculation. Spores were resuspended in $50 \mathrm{mM}$ Tris/ $\mathrm{HCl}$ buffer $(\mathrm{pH} 7 \cdot 0$ ) containing $10 \%(\mathrm{v} / \mathrm{v})$ glycerol, $10 \mu \mathrm{g}$ antipain $\mathrm{ml}^{-1}, 10 \mu \mathrm{g}$ soybean trypsin inhibitor $\mathrm{ml}^{-1}, 1 \mathrm{mM}$ PMSF, $5 \mathrm{mM}$ EGTA and $5 \mathrm{mM}$ EDTA, and disrupted in a Braun homogenizer for $180 \mathrm{~s}$ while cooling with a stream of $\mathrm{CO}_{2}$. The crude extract was centrifuged at $100000 \mathrm{~g}\left(r_{\mathrm{av}}\right)$ for $60 \mathrm{~min}$ at $4{ }^{\circ} \mathrm{C}$. The supernatant $(\mathrm{S} 31 \mathrm{~K})$ was used as cytosolic fraction for the ADP-ribosylation assays.

ADP-ribosylation assay. The $\mathrm{S} 31 \mathrm{~K}$ fraction $(100 \mu \mathrm{g})$ was added to the incubation mixture (final volume $40 \mu \mathrm{l}$ ) containing $40 \mathrm{mM}$ Tris/HCl (pH 7.4), $10 \mathrm{mM}$ DTT, $5 \mu \mathrm{M}\left[{ }^{32} \mathrm{P}\right] \mathrm{NAD}$ $(5 \mu \mathrm{Ci}$ per assay; $1 \mu \mathrm{Ci}=37 \mathrm{kBq}), 10 \mathrm{mM} \mathrm{MgCl}_{2}, 1 \mathrm{mM} \mathrm{ATP}$, $1 \mathrm{mM}$ GTP. Incubation was carried out for $1.5 \mathrm{~h}$ at $37^{\circ} \mathrm{C}$ and the reaction was terminated with $4 \times \mathrm{SDS}$ gel loading buffer $[0.25 \mathrm{M}$ Tris/ $\mathrm{HCl}, \mathrm{pH} 6.8,4 \%$ (w/v) SDS, $20 \% \quad(\mathrm{v} / \mathrm{v})$ glycerol, $10 \%$ (v/v) 2-mercaptoethanol]. Samples were boiled for $3 \mathrm{~min}$ and separated by $10 \%$ SDS-PAGE (Laemmli, 1970). Gels were fixed, stained with Coomassie brilliant blue R-250, destained and dried. Dry gels were exposed for 1 week to XOMAT films for autoradiography.

GAPDH activity assay. GAPDH activity of the S31K fraction and of partially purified preparations was monitored by following the reduction of $\mathrm{NAD}^{+}$to $\mathrm{NADH}$ at $340 \mathrm{~nm}$ as described by Shu-Chan \& Moulday (1990). All assays were carried out in $30 \mathrm{mM}$ pyrophosphate buffer, $\mathrm{pH} 8 \cdot 4$, in a final volume of $1 \mathrm{ml}$, containing $12 \mathrm{mM}$ sodium arsenate, $1 \mathrm{mM}$ $\mathrm{NAD}^{+}$and $1.5 \mathrm{mM}$ GA3P. One milliunit (mU) of enzyme activity is defined as the production of $1 \mu \mathrm{mol} \mathrm{NADH} \mathrm{min}^{-1}$ (mg protein) $)^{-1}$ using $6 \cdot 22 \mathrm{mM}^{-1} \mathrm{~cm}^{-1}$ as the absorption coefficient for NADH.

Partial purification. The cytosolic fraction $(50 \mathrm{ml})$ containing $30 \mathrm{mg}$ total protein was separated by isoelectric focusing in a Rotofor Cell (Bio-Rad) for an initial fractionation in a widerange $\mathrm{pH}$ gradient $(\mathrm{pH} 3-10$; ampholytes were used at a final concentration of $2 \%$ ). Constant power $(15 \mathrm{~W})$ was applied for $5 \mathrm{~h}$ at $4{ }^{\circ} \mathrm{C}$. Runs were terminated when the voltage had stabilized for about $30 \mathrm{~min}$. Twenty Rotofor fractions were collected, and each fraction was assayed for ADP-ribosyl- transferase activity. $\left[{ }^{32} \mathrm{P}\right] \mathrm{ADP}$-ribosylated proteins were analysed by SDS-PAGE. Fractions in which [ $\left.{ }^{32} \mathrm{P}\right]$ ADP-ribosylated proteins were detected were pooled and further separated by a second isoelectric focusing in the Rotofor Cell using a narrow $\mathrm{pH}$ gradient $(\mathrm{pH} 5 \cdot 7-6 \cdot 0)$. An ADP-ribosylation assay was carried out on each of the 20 Rotofor fractions, and those with activity were pooled. The pool was divided into two parts, one of which was loaded onto a Superdex 200 HR 10/30 column. The column was equilibrated with $50 \mathrm{ml}$ (two column volumes) of elution buffer $(50 \mathrm{mM}$ Tris/ $\mathrm{HCl}, \mathrm{pH} 7 \cdot 5)$. The sample $(0.5 \mathrm{ml})$ was loaded and eluted with the same buffer into $0.3 \mathrm{ml}$ fractions. Protein content was estimated by absorbance at $280 \mathrm{~nm}$. The collected fractions were analysed by $10 \%$ SDS-PAGE. The other part of the pool was used for $\mathrm{N}$-terminal sequencing. Basically, the proteins were incubated with $\left[{ }^{32} \mathrm{P}\right] \mathrm{NAD}$ and separated by preparative SDS-PAGE followed by transfer to a PVDF membrane and staining with Coomassie blue. The $37 \mathrm{kDa}\left[{ }^{32} \mathrm{P}\right] \mathrm{ADP}$-ribosylated protein was visualized by autoradiography and N-terminally sequenced by Bio-Synthesis (Lewisville, TX, USA).

Chemical stability of the ADP-ribose-protein bond. This was determined as previously described (Aktories et al., 1988). One sample was incubated for $60 \mathrm{~min}$ under ADP-ribosylation conditions as described above, and then divided into four portions. Each of these was treated with $1 \mathrm{M}$ hydroxylamine ( $\mathrm{pH} 7 \cdot 5), 2 \mathrm{mM} \mathrm{HgCl}_{2}, 50 \%$ formic acid or water. Incubation was carried out for $60 \mathrm{~min}$ at $30^{\circ} \mathrm{C}$ and samples were processed for electrophoresis.

Protein determination. Protein concentration was estimated by the Lowry method, using serum bovine albumin as standard.

\section{RESULTS}

\section{Identification of a $37 \mathrm{kDa}$ ADP-ribosylated protein from the S31K fraction in P. blakesleeanus}

Soluble extracts of spores of $P$. blakesleeanus presented a broad band of a $\left[{ }^{32} \mathrm{P}\right] \mathrm{ADP}$-ribosylated protein with a molecular mass of $37 \mathrm{kDa}$ which was separated into three major proteins of $38 / 6.9,37 / 8.1$ and $36 / 4 \cdot 1 \mathrm{kDa} / \mathrm{pI}$ after two-dimensional electrophoresis (Deveze-Alvarez et al., 1996). Two additional [ $\left.{ }^{32} \mathrm{P}\right]$ ADPribosylated proteins of 55 and $57 \mathrm{kDa}$ were observed when these extracts were incubated under ADP-ribosylation conditions in the absence of $\mathrm{MgCl}_{2}$ (DevezeAlvarez et al., 1996). In order to purify and characterize the $37 \mathrm{kDa}$ protein, the $\mathrm{S} 31 \mathrm{~K}$ proteins were separated by two sequential isoelectrofocusing steps. The fractions which presented a $\left.{ }^{32} \mathrm{P}\right]$ ADP-ribosylated protein with a molecular mass of $37 \mathrm{kDa}$ were pooled, concentrated, and N-terminally microsequenced. The obtained sequence of this region of the protein (1VKVGVNGFGRIGRLV15) was identical to the GAPDH N-terminal sequence in human, mouse and rabbit, and showed strong homology ( $86 \%$ identity) with sequences from other fungi such as Neurospora crassa (Sahni \& Kinsey, 1997), Podospora anserina (Ridder \& Osiewacz, 1992), Cryphonectria parasitica (Choi \& Nuss, 1990), Cochliobolus heterostrophus (Van Wert \& Yoder, 1992), Candida albicans (Gil-Navarro et al., 1997), Claviceps purpurea (Jungehulsing et al., 1994), Schizophyllum commune and Agaricus bisporus (Harmsen et al., 1992). 
Table 1. ADP-ribosylation of GAPDH measured by ${ }^{14} \mathrm{C}$ incorporation from [nicotinamide $-{ }^{14} \mathrm{C}$ ]NAD or [adenine $-{ }^{14} \mathrm{C}$ ]NAD

Proteins $(100 \mu \mathrm{g})$ were incubated with [nicotinamide $\left.-{ }^{14} \mathrm{C}\right] \mathrm{NAD}$ $\left(\left[\right.\right.$ nic $\left.\left.-{ }^{14} \mathrm{C}\right] \mathrm{NAD}\right)$ or $\left[\right.$ adenine $\left.-{ }^{14} \mathrm{C}\right] \mathrm{NAD}\left(\left[\right.\right.$ ade $\left.\left.^{-1}{ }^{14} \mathrm{C}\right] \mathrm{NAD}\right)$ under ADP-ribosylation conditions as described in Methods. Incubation was carried out for $1.5 \mathrm{~h}$ at $37^{\circ} \mathrm{C}$ and the reaction was terminated by the addition of $20 \%$ TCA (final concentration). Samples were filtered through Whatman paper filters and incorporated radioactivity was counted in a spectrophotometer.

\begin{tabular}{|c|c|c|c|}
\hline Sample & $\begin{array}{c}{\left[\text { nic }^{-14} \mathrm{C}\right] \text { NAD }} \\
(\mathrm{a})\end{array}$ & $\begin{array}{c}{\left[a d e-{ }^{14} \mathrm{C}\right] \text { NAD }} \\
\text { (b) }\end{array}$ & $\begin{array}{l}\text { Ratio } \\
(\mathbf{a}) /(\mathbf{b})\end{array}$ \\
\hline S31K & $0 \cdot 1 \times 10^{-10}$ & $1 \cdot 1 \times 10^{-10}$ & 0.09 \\
\hline IEF fraction & $0 \cdot 72 \times 10^{-10}$ & $5 \cdot 36 \times 10^{-10}$ & $0 \cdot 13$ \\
\hline
\end{tabular}

\section{NAD-dependent post-translational modification of GAPDH}

McDonald \& Moss (1993) reported that nitric oxide (NO) induces a covalent binding of NAD to GAPDH through a non-enzymic process. To study the mechanism involved in the modification of GAPDH, we incubated the fraction enriched for the $37 \mathrm{kDa}$ protein with either [adenine $\left.-{ }^{14} \mathrm{C}\right] \mathrm{NAD}$ or [nicotinamide${ }^{14} \mathrm{C}$ ]NAD. Table 1 shows that a significant level of radioactivity was incorporated into the protein when the fraction was incubated with [adenine $\left.-{ }^{14} \mathrm{C}\right] \mathrm{NAD}$, but not when it was incubated with the [nicotinamide$\left.{ }^{14} \mathrm{C}\right]$ NAD. Furthermore, the labelling of the $37 \mathrm{kDa}$ protein did not occur when the fraction was heatdenatured, suggesting an enzymic modification of the protein (data not shown). These results demonstrate that the GAPDH is modified by a mono(ADP-ribosyl) transferase activity present in $P$. blakesleeanus spores.

\section{Arginine is the amino acid acceptor of the ADP-ribose in the GAPDH}

We have previously reported the presence of an argininespecific ADP-ribosyltransferase in spores of Phycomyces (Deveze-Alvarez et al., 1996). An examination of the stability of the bond between the ${ }^{32} \mathrm{P}$-label and the $37 \mathrm{kDa}$ protein (GAPDH) of P. blakesleeanus revealed that the intensity of the labelling was not reduced by treatment with $2 \mathrm{mM} \mathrm{HgCl}_{2}, 1 \mathrm{M}$ Tris/ $\mathrm{HCl} \mathrm{pH} \mathrm{9.0} \mathrm{or}$ formic acid, but was slightly diminished with $\mathrm{NH}_{2} \mathrm{OH}$ (data not shown). These results established that the $\left[{ }^{32} \mathrm{P}\right]$ ADP-ribosylation of GAPDH does not occur through a thiol linkage to a cysteine, which is a common site for NO-catalysed covalent modification of this enzyme by radiolabelled $\mathrm{NAD}^{+}(\mathrm{McD}$ onald \& Moss, 1993). We can also rule out the amino acid that is involved in bonding of ADP-ribose-GAPDH as reported by De Matteis et al. (1994) since this bond is sensitive to formic acid. We conclude that the GAPDH of $P$. blakesleeanus is in vitro post-translationally ADP-
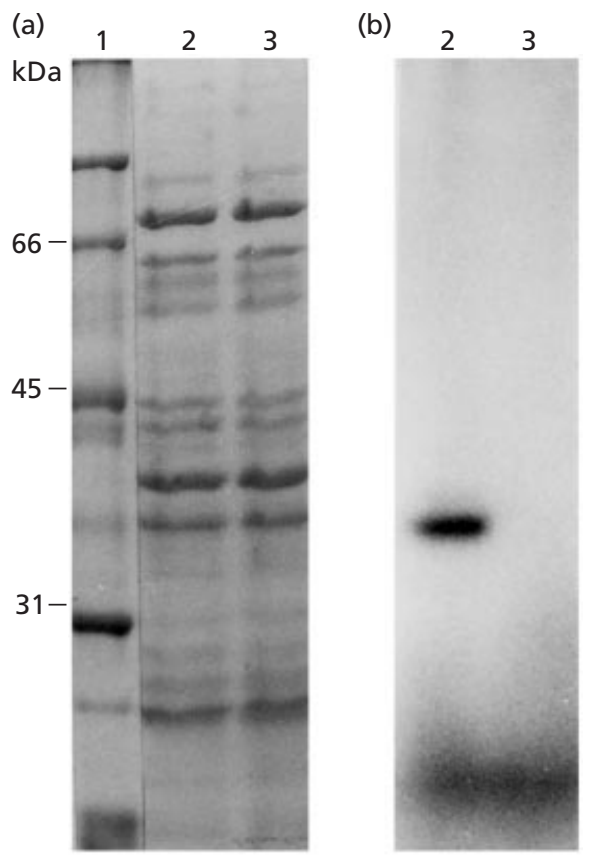

Fig. 1. Effect of GA3P on the ADP-ribosylation of the $37 \mathrm{kDa}$ protein. The S31K fraction was incubated with [ $\left.{ }^{32} \mathrm{P}\right] N A D$ in the absence (lane 2) or presence (lane 3) of GA3P under ADPribosylation conditions. The proteins were separated by SDSPAGE, stained with Coomassie blue (a), dried, and analysed by autoradiography (b). Lane 1, molecular mass markers.

ribosylated on an arginine residue. This is the first report of a modification by this enzyme on an arginine residue of GAPDH.

\section{Regulation of GAPDH activity by its substrate and by ADP-ribosylation}

The influence of ADP-ribosylation on GAPDH activity in the S31K fraction was examined. GAPDH activity was measured in the absence or presence of ADPribosylation conditions. GAPDH activity (1417 \pm 149 units ; $n=3$ ) was inhibited approximately 50\% (637 \pm 64 units; $n=3$ ) when assayed under ADP-ribosylation conditions.

We also studied the effects of GA3P, the substrate for the GAPDH, on the ADP-(ribosyl)transferase activity. Fig. 1 shows that the presence of GA3P in the reaction affected the $\left[{ }^{32} \mathrm{P}\right]$ ADP-ribosylation of the GAPDH. These findings suggest that both ADP-ribosylation and GA3P may play regulatory roles in determining activity of GAPDH.

\section{ADP-ribosylation during the germination process of P. blakesleeanus}

ADP-ribosylation of proteins has a role in the development of different organisms (Eastman \& Dworkin, 1994; Huh et al., 1996; Shima et al., 1996). Previously, we reported that different ADP-ribosylation inhibitors affected the germination of $P$. blakesleeanus spores, 
(a)

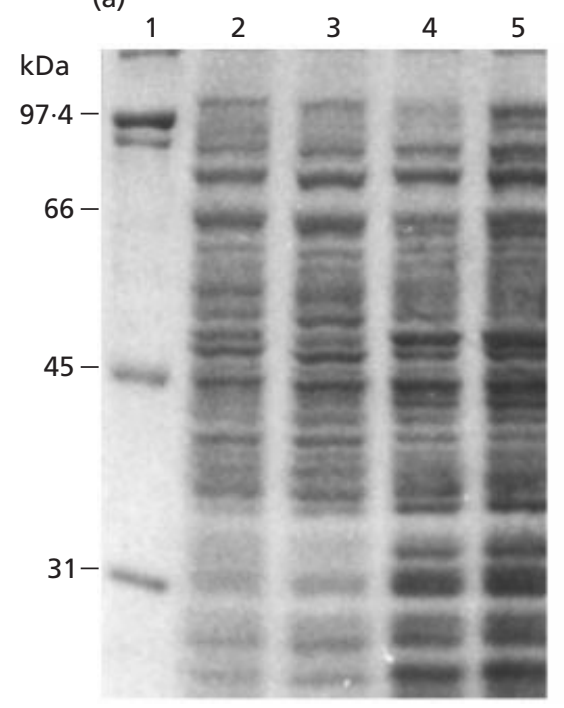

(b)

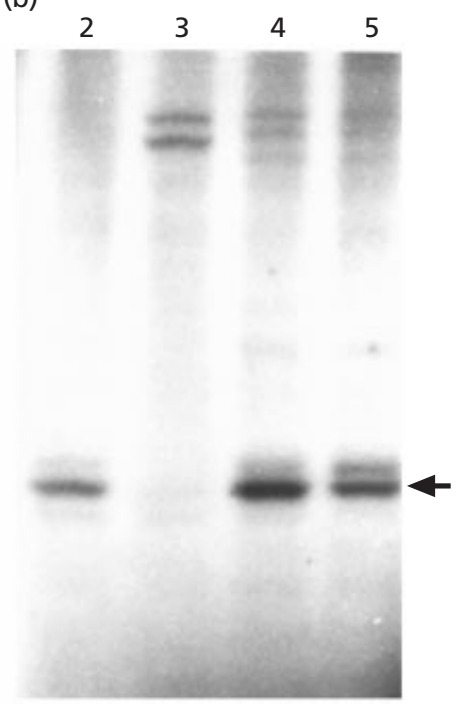

Fig. 2. Endogenous ADP-ribosylation of $P$. blakesleeanus proteins during the germination process. The $S 31 \mathrm{~K}$ fraction was obtained from cultures at the times of germination indicated below. Samples $(100 \mu \mathrm{g})$ from each time point were ADPribosylated as described in Methods. (a) Coomassie stain; (b) autoradiography. The $37 \mathrm{kDa}$ band corresponding to GAPDH is arrowed. Lanes: 1, molecular mass markers; 2 , dormant spores; 3 , spores $0.5 \mathrm{~h}$ after activation; 4 , swelling spores (4 $\mathrm{h}$ after activation); 5 , cells with a germ-tube with half the size of the spore ( $5.5 \mathrm{~h}$ after activation).

leaving them as swollen cells (Deveze-Alvarez et al., 1996). Bearing this in mind, we analysed the expression pattern of the ADP-ribosylated proteins during different stages of the cellular differentiation of P. blakesleeanus. Samples used for the ADP-ribosylation assays corresponded to dormant spores, and spores $0.5 \mathrm{~h}, 4 \mathrm{~h}$ and $5.5 \mathrm{~h}$ after activation (Fig. 2). Under the conditions used, spore swelling occurred during the first $4 \mathrm{~h}$ and germtube formation started at about $5.5 \mathrm{~h}$ of incubation at $24^{\circ} \mathrm{C}$. Analysis of labelled (ADP-ribosylated) cellular proteins from the different stages of differentiation showed that (i) several proteins are ribosylated throughout germination (Fig. 2b), and (ii) the GAPDH is ADPribosylated to a variable level (Fig. 2b). Remarkably, the level of ADP-ribosylation of GAPDH decreased $0.5 \mathrm{~h}$ after spore activation, but then reached a level comparable to the dormant spore after 4-5 h (Fig. 2b). Two $\left[{ }^{32} \mathrm{P}\right]$ ADP-ribosylated proteins, of 79 and $83 \mathrm{kDa}$, respectively, were detected $30 \mathrm{~min}$ after activation and afterwards. We do not know the nature of these proteins (Fig. 2b).

\section{GAPDH activity during germination in P. blakesleeanus}

As shown above, the GAPDH activity from spore extracts was inhibited when assayed under ADP-ribosylation conditions. We therefore examined GAPDH activity during spore germination. The enzymic activity was measured in samples obtained from the same time points as above. The GAPDH activity in spores was $1250 \pm 250 \mathrm{mU}$ and it increased strongly at $0.5 \mathrm{~h}(3500 \pm$ $700 \mathrm{mU})$; at 4 and $5.5 \mathrm{~h}$ of growth, this activity decreased to levels $(1050 \pm 200 \mathrm{mU})$ comparable to those found in dormant spores. Therefore, a correlation between the ADP-ribosylation and activity of GAPDH exists during this stage of the germination. Thus, ADP-ribosylated GAPDH is associated with a decrease in its enzymic activity. Additionally, activity is only detected at low levels of ADP-ribosylation of GAPDH.

\section{DISCUSSION}

Our work has identified the enzyme GAPDH as one of the substrates of the arginine specific ADP-(ribosyl)transferase of Phycomyces. Brüne \& Lapetina (1989) reported that NO stimulates the auto-ADP-ribosylation of a $39 \mathrm{kDa}$ protein in platelets. Subsequently, the $39 \mathrm{kDa}$ protein was identified as GAPDH (Dimmeler et al., 1992). These authors also reported that NOmediated ADP-ribosylation of GAPDH inhibited this enzyme activity. Several investigators have questioned whether or not auto-ADP-ribosylation of GAPDH occurs as a result of stimulation by $\mathrm{NO}(\mathrm{McDonald} \&$ Moss, 1993; Itoga et al., 1997).

De Matteis et al. (1994) reported that in rat basophilic leukaemia cells, brefeldin A, a fungal metabolite, stimulates the ADP-ribosylation of two cytosolic proteins of 38 and $50 \mathrm{kDa}, \mathrm{p} 38$ and p50, respectively. p38 appears to be identical with an isoform of GAPDH. They assessed the level of chemical reactivity of the brefeldin Astimulated linkage of radiolabel from $\left[{ }^{32} \mathrm{P}\right] \mathrm{NAD}$ with GAPDH and reported that the incorporated radioactivity was stable to treatment with $\mathrm{NH}_{2} \mathrm{OH}$ or $\mathrm{HgCl}_{2}$, but was sensitive to acid and base, suggesting that brefeldin A induced a novel type of amino acid modification, different from those previously reported. Kots et al. (1993) reported that the ADP-ribosylation of 
the GAPDH is activated not only by NO, but also by its substrate GA3P, and suggested that a lysine $\varepsilon$-amino group is the target for the ADP-ribose. In this work we found that the ADP-ribosylation of the GAPDH in spores of $P$. blakesleeanus appears to be mediated by a specific binding of ADP-ribose to an arginine residue. Recently, we reported the presence of three proteins of molecular masses of 38,37 and $36 \mathrm{kDa}$ in spores of $P$. blakesleeanus as possible substrates of an argininespecific mono(ADP-ribosyl)transferase (Deveze-Alvarez et al., 1996). In this work, we have identified the $37 \mathrm{kDa}$ protein as GAPDH.

Although ADP-ribosylation by bacterial toxins has been extensively elucidated, mammalian ADP-ribosyltransferases have only recently been characterized (KochNolte \& Haag, 1997). The best-studied substrates have been the elongation factor 2 , guanine nucleotide binding proteins, and structural proteins.

Bacterial ADP-ribosyltransferases are usually described as exotoxins whose targets are eukaryotic proteins. Evidence is being reported that there is a family of bacterial ADP-ribosyltransferases that function as endogenous regulators. For example, ADP-ribosylation plays a key role in the regulation of dinitrogen fixation in Rhodospirillum rubrum (Fu et al., 1990) and in the development of Streptomyces coelicolor (Ochi et al., 1992; Penyge et al., 1992) and Myxococcus xanthus (Eastman \& Dworkin, 1994). Reich \& Schoolnik (1996) have suggested that the ADP-ribosyltransferase of Vibrio fischeri may participate in signalling during its symbiotic association with Euprymna scolopes.

The physiological importance of ADP-ribosylation in fungi is not known. In this work, we found that when soluble extracts of Phycomyces spores were incubated under ADP-ribosylation conditions before the GAPDH assay, a decrease of this enzymic activity was observed. This inhibition was overcome by the addition of GA3P to the ADP-ribosylation assay. This result suggests that probably the interaction of GA3P with GAPDH may affect the binding of ADP-ribose to the enzyme, consequently allowing GAPDH to remain active.

On the other hand, the profile of protein $\left[{ }^{32} \mathrm{P}\right] \mathrm{ADP}-$ ribosylation during germination indicates that the ADPribosylation of GAPDH is physiologically regulated in P. blakesleeanus and that the ADP-ribosylation of this enzyme could influence the energy metabolism and nonglycolytic functions of the fungus. The first common effect of different spore-activating treatments in $P$. blakesleeanus is a transient rise in cAMP content (Van Mulders \& Van Laere, 1984). cAMP transiently activates trehalase and glycerol-3-phosphatase in spores (Van Laere et al., 1987). The activation of these enzymes causes a quick decrease in trehalose with an associated increase in glycerol. Production of glycerol would be the most protective strategy, as glycerol can leak out of the membrane without damage and, unlike ethanol and lactate, it does not inhibit, but rather protects enzymic activity (Van Laere, 1986). We postulate that in the dormant spore, all the trehalose can be converted to glycerol. This can result from activation of glycerol-3phosphatase and reduced levels of glycolysis caused by inactivation of GAPDH by ADP-ribosylation. Glucose can then be transported and some converted to GA3P, which will protect GAPDH from ADP-ribosylation, allowing glycolysis to continue at a faster rate. Our current working model predicts that ADP-ribosylation and GA3P regulate the metabolic flux of glucose towards glycerol, glycolysis, pentose phosphate or GAPDH activity through non-glycolytic functions. Further work is required to determine whether this is correct.

Although GAPDH has been characterized as a glycolytic enzyme, it is in fact a multifunctional protein and has been implicated in several cellular activities, including the nuclear export of tRNA (Sing \& Green, 1993), the regulation of actin filaments in microfilaments (Fuchtbauer et al., 1986; Huiterol \& Pantaloni, 1985), DNA repair (Meyer-Sieglet et al., 1991), and the regulation of calcium release from the endoplasmic reticulum (Kim et al., 1990). The physiological role of the ADP-ribosylation of GAPDH needs further exploration. Since this enzyme plays an important role in glycolysis and in a number of non-glycolytic pathways as described above, variations in GAPDH activity could influence many other cellular activities, facilitating adaptation to different environmental challenges or growth conditions.

\section{ACKNOWLEDGEMENTS}

This work was supported by the Consejo Nacional de Ciencia y Tecnología of México (Grants N3132P). We gratefully thank Dr José Arnau for critical reading of the manuscript.

\section{REFERENCES}

Aktories, K., Just, I. \& Rosenthal, W. (1988). Different types of ADP-ribose protein bonds formed by botulinum $\mathrm{C} 2$ toxin, botulinum ADP-ribosyltransferase C3 and pertussis toxin. Biochem Biophys Res Commun 156, 361-367.

Bartnicki-García, S. \& Nickerson, W. J. (1962). Nutrition, growth, and morphogenesis of Mucor rouxii. J Bacteriol 84, 841-858.

Brüne, B. \& Lapetina, E. G. (1989). Activation of a cytosolic ADPribosyltransferase by nitric oxide-generating agents. J Biol Chem 264, 8455-8458.

Choi, G. H. \& Nuss, D. L. (1990). Nucleotide sequence of the glyceraldehyde-3-phosphate dehydrogenase gene from Cryphonectria parasitica. Nucleic Acids Res 18, 5566.

De Matteis, M. A., Di Girolamo, M., Colanzi, A. \& 8 other authors (1994). Stimulation of endogenous ADP-ribosylation by brefeldin A. Proc Natl Acad Sci US A 91, 1114-1118.

Deveze-Alvarez, M. A., García-Soto, J. \& Martínez-Cadena, G. (1996). Evidence for an arginine-specific mono(ADP-ribosyl) transferase in dormant spores of the fungus Phycomyces blakesleeanus. Microbiology 142, 2907-2912.

Dimmeler, S., Lottspeich, F. \& Brüne, B. (1992). Nitric oxide causes ADP-ribosylation and inhibition of glyceraldehyde-3phosphate dehydrogenase. J Biol Chem 267, 16771-16774.

Eastman, D. \& Dworkin, M. (1994). Endogenous ADP-ribosylation during development of the prokaryote Myxococcus xanthus. Microbiology 140, 3167-3176. 
Fu, H. R., Burris, H. \& Roberts, G. P. (1990). Reversible ADPribosylation is demostrated to be a regulatory mechanism in prokaryotes by heterologous expression. Proc Natl Acad Sci U S A 87, 1720-1724.

Fuchtbauer, A., Jockusch, B. M., Leberer, E. \& Pette, D. (1986). Actin-severing activity copurifies with phosphofructokinase. Proc Natl Acad Sci U S A 83, 9502-9506.

Gil-Navarro, I., Gil, M. L., Casanova, M., O’Connor, J. E., Martinez, J. P. \& Gozalbo, D. (1997). The glycolytic enzyme glyceraldehyde3-phosphate dehydrogenase of Candida albicans is a surface antigen. J Bacteriol 179, 4992-4999.

Harmsen, M. C., Schuren, F. H., Moukha, S. M., van Zuilen, C. M., Punt, P. J. \& Wessels, J. G. (1992). Sequence analysis of the glyceraldehyde-3-phosphate dehydrogenase genes from the basidiomycetes Schizophyllum commune, Phanerochaete chrysosporium and Agaricus bisporus. Curr Genet 22, 447-454.

Huiterol, P. \& Pantaloni, D. (1985). Bundling of microtubules by glyceraldehyde-3-phosphate dehydrogenase and its modulation by ATP. Eur J Biochem 150, 265-269.

Huh, K. W., Shima, J. \& Ochi, K. (1996). ADP-ribosylation of proteins in Bacillus subtilis and its possible importance in sporulation. J Bacteriol 178, 4935-4941.

Itoga, M., Tsuchiya, M., Ishino, H. \& Shimoyama, M. (1997). Nitric oxide-induced modification of glyceraldehyde-3-phosphate dehydrogenase with $\mathrm{NAD}^{+}$is not ADP-ribosylation. J Biochem 121, 1041-1046.

Jacobson, M. K., Loflin, P. T., Aboul-Ela, N., Minmuang, M., Moss, J. \& Jacobson, E. L. (1990). Modification of plasma membrane protein cysteine residues by ADP-ribose in vivo. J Biol Chem $\mathbf{2 6 5}$, 10825-10828.

Jungehulsing, U., Arntz, C., Smit, R. \& Tudzynski, P. (1994). The Claviceps purpurea glyceraldehyde-3-phosphate dehydrogenase gene: cloning, characterization, and use for the improvement of a dominant selection system. Curr Genet 25, 101-106.

Kim, K. C., Caswell, A. H., Talvenheimo, J. A. \& Brandt, N. R. (1990). Isolation of a terminal cisterna protein which may link the dihydropyridine receptor to the junctional foot protein in skeletal muscle. Biochemistry 29, 9281-9289.

Koch-Nolte, F. \& Haag, F. (1997). Mono(ADP-ribosyl)transferases and related enzymes in animal tissues. In ADP-ribosylation in Animal Tissues: Structure, Function, and Biology of Mono(ADPribosyl)transferases and Related Enzymes (Advances in Experimental Medicine and Biology 419), pp. 1-13. Edited by F. Haag \& F. Koch-Nolte. New York: Plenum.

Kots, A. Ya., Sergienko, E. A., Bulargina, T. V. \& Severin, E. S. (1993). Glyceraldehyde-3-phosphate activates auto-ADP-ribosylation of glyceraldehyde-3-phosphate dehydrogenase. FEBS Lett 324, 33-36.

Laemmli, U. K. (1970). Cleavage of structural proteins during the assembly of the head of bacteriophage T4. Nature 227, 680-685.

McDonald, L. J. \& Moss, J. (1993). Stimulation by nitric oxide of an NAD linkage to glyceraldehyde-3-phosphate dehydrogenase. Proc Natl Acad Sci U S A 90, 6238-6241.

Martínez-Cadena, G. \& Ruiz-Herrera, J. (1987). Activation of chitin synthetase from Phycomyces blakesleeanus by calcium and calmodulin. Arch Microbiol 148, 280-285.

Meyer-Sieglet, K., Mauro, D. J., Seal, G., Wurzer, J., Deriel, J. K. \& Sirover, M. A. (1991). A human uracil DNA glycosylase is the $37-$ $\mathrm{kDa}$ subunit of glyceraldehyde-3-phosphate dehydrogenase. Proc Natl Acad Sci U S A 88, 8460-8464.
Moss, J., Jacobson, M. K. \& Stanley, S. J. (1985). Reversibility of arginine-specific mono(ADP-ribosyl)ation: identification in erythrocytes of an ADP-ribose-L-arginine cleavage enzyme. Proc Natl Acad Sci US A 82, 5603-5607.

Ochi, K., Penyge, A. \& Barabas, G. (1992). The possible role of ADP-ribosylation in sporulation and streptomycin production by Streptomyces griseus. J Gen Microbiol 138, 1745-1750.

Penyge, A., Vargha, G., Ensign, J. C. \& Barabás, G. (1992). The possible role of ADP-ribosylation in physiological regulation of sporulation in Streptomyces griseus. Gene 115, 181-185.

Reich, K. \& Schoolnik, G. K. (1996). Halovibrin, secreted from the light organ symbiont Vibrio fischeri, is a member of a new class of ADP-ribosyltransferases. J Bacteriol 178, 209-215.

Ridder, R. \& Osiewacz, H. D. (1992). Sequence analysis of the gene coding for glyceraldehyde-3-phosphate dehydrogenase $(g p d)$ of Podospora anserina: use of homologous regulatory sequences to improve transformation efficiency. Curr Genet 21, 207-213.

Sahni, M. \& Kinsey, J. A. (1997). Identification and cloning of the Neurospora crassa glyceraldehyde-3-phosphate dehydrogenase gene, gpd-1. Fungal Genet Newsl 44, 47-49.

Shima, J., Penyge, A. \& Ochi, K. (1996). Changes in patterns of ADP-ribosylated proteins during differentiation of Streptomyces coelicolor A3(2) and its developmental mutants. J Bacteriol 178, 3785-3790.

Shu-Chan, H. \& Molday, R. S. (1990). Glyceraldehyde-3-phosphate dehydrogenase is a major protein associated with the plasma membrane of retinal photoreceptor outer segments. J Biol Chem 265, 13308-13313.

Sing, R. \& Green, M. R. (1993). Sequence-specific binding of transfer RNA by glyceraldehyde-3-phosphate dehydrogenase. Science 259, 365-368.

Van Laere, A. J. (1986). Biochemistry of spore germination in Phycomyces. FEMS Microbiol Rev 32, 189-198.

Van Laere, A. J. \& Hendrix, P. (1983). Cyclic AMP-dependent in vitro activation of trehalase from dormant Phycomyces blakesleeanus spores. J Gen Microbiol 129, 3287-3290.

Van Laere, A. J., Van Assche \& Furch, B. (1987). The sporangiospore: dormancy and germination. In Phycomyces, pp. 247-279. Edited by E. Cerdá-Olmedo \& E. D. Lipson. Cold Spring Harbor, NY : Cold Spring Harbor Laboratory.

Van Mulders, R. \& Van Laere, A. J. (1984). Cyclic AMP, trehalase and germination of Phycomyces blakesleeanus spores. J Gen Microbiol 130, 541-547.

Van Schaftingen, E. \& Van Laere, A. J. (1985). Glycerol formation after the breaking of dormancy of Phycomyces blakesleeanus spores. Eur J Biochem 148, 399-404.

Van Wert, S. L. \& Yoder, O. C. (1992). Structure of the Cochliobolus heterostrophus glyceraldehyde-3-phosphate dehydrogenase gene. Curr Genet 22, 29-35.

Williamson, K. C. \& Moss, J. (1990). Mono-ADP-ribosyltransferases and ADP-ribosylarginine hydrolases: a mono ADPribosylation cycle in animal cells. In ADP-ribosylating Toxins and G Proteins: Insights into Signal Transduction, pp. 493-510. Edited by J. Moss \& M. Vaughan. Washington, DC: American Society for Microbiology.

Received 9 November 2000; revised 12 March 2001; accepted 9 May 2001. 